\title{
Dynamics of Abies spectabilis in Relation to Climate Change at the Treeline Ecotone in Langtang National Park
}

\author{
Narayan P. Gaire ${ }^{1 *}$, Yub R. Dhakal ${ }^{2}$, Harish C. Lekhak ${ }^{2}$, Dinesh R. Bhuju ${ }^{1}$ and \\ Santosh K. Shah ${ }^{3}$ \\ ${ }^{1}$ Nepal Academy of Science and Technology (NAST), Kathmandu \\ ${ }^{2}$ Central Department of Environment Science, Tribhuvan University, Kathmandu \\ ${ }^{3}$ Birbal Sahni Institute of Paleobotany, Lucknow, India \\ e-mail: npgaire2007@gmail.com
}

\begin{abstract}
This paper is aimed to study the tree line dynamics of Himalayan silver fir (Abies spectabilis D. Don) based on its tree-ring data and age stand distribution at Langtang National Park, Central Nepal. Climatic response on radial growth, recruitment of $A$. spectabilis and its age distribution are carried out. The average tree density of the species in the study area (total 48 plots of $20 \mathrm{~m}$ x $20 \mathrm{~m}$ ) was $236 \mathrm{no} /$ ha while that for sapling and seedling in the study area was 255 and 350 no/ha, respectively. The stand character and age distribution of the species showed a high level of recruitment in the recent decades, with decreased in average age along with increased altitude. Tree-growth climate relationship showed negative response with temperature of March-May. Upward advancement of tree line is expected in the coming recent decades though not necessarily uniform through the line.
\end{abstract}

Key Words: dendrochronology, regeneration, stand age dynamics, tree density, DBH

\section{Introduction}

Climate change is a major concern in the Himalaya because of its negative impacts on the economy, ecology, and environment of the region including areas downstream (Schild 2007). Studies have revealed temperature warming in Nepal with more pronounced effect at higher elevation (Shrestha et al. 1999). The tree line, a life form boundary that limits regional tree growth irrespective of the species (Becker et al. 2007), is applied to open canopy forest (Körner 1998). As the tree line determines the lower boundary limits of the alpine belt, any upward shift of the tree line will restrict the overall alpine area and impacts the distribution of alpine species with a lower species affiliation (Becker et al. 2007). The tree line ecotones are sensitive biomonitors of past and recent climate change and variability (Kullman 1998, Camarero \& Gutiérrez 2004) and which are ideally suited for climate change monitoring (Becker et al., 2007). Trees at tree line often respond to climatic warming with increase in recruitment or tree-density, as well as upward advances in the tree line (Bradley \& Jones 1993, Camarero \& Gutiérrez 2004). The demographic structure of a stand can provide a picture of temporal variations in the 
establishment rate. On the other hand, a static age structure of living trees is the expression of change in the rate of tree recruitment and mortality over time (Harcombe 1987).

Tree-ring analysis coupled with stand age structures, climatic data and ecological attributes of individual species is an appropriate approach for understanding long-term forest or tree line dynamics (Abrams et al. 1998, Wang et al. 2006). In Nepal, studies have shown suitability of many trees species for dendrochronological study (Suzuki 1990, Bhattacharyya et al. 1992, Cook et al. 2003, Bräuning 2004, Sano et al. 2005) and climate reconstruction based on tree-ring analysis are have recently been established (Cook et al. 2003, Sano et al. 2005). However, studies on forest or tree line dynamics with climate change using tree-ring data coupled with other ecological study are limited (Bhuju et al. 2010).

Realizing the importance of the tree line for long term monitoring, this study aims to keep geo-referenced baseline information on ecological and dendrochronological aspect of the tree line, and in particular current regeneration status, dynamics, and growth trends of Abies spectabilis at its upper distribution limit in the Langtang National Park (LNP), central Nepal Himalaya. The study also analyzed tree growth relationship and regeneration of the species.

\section{Methodology Study site and species}

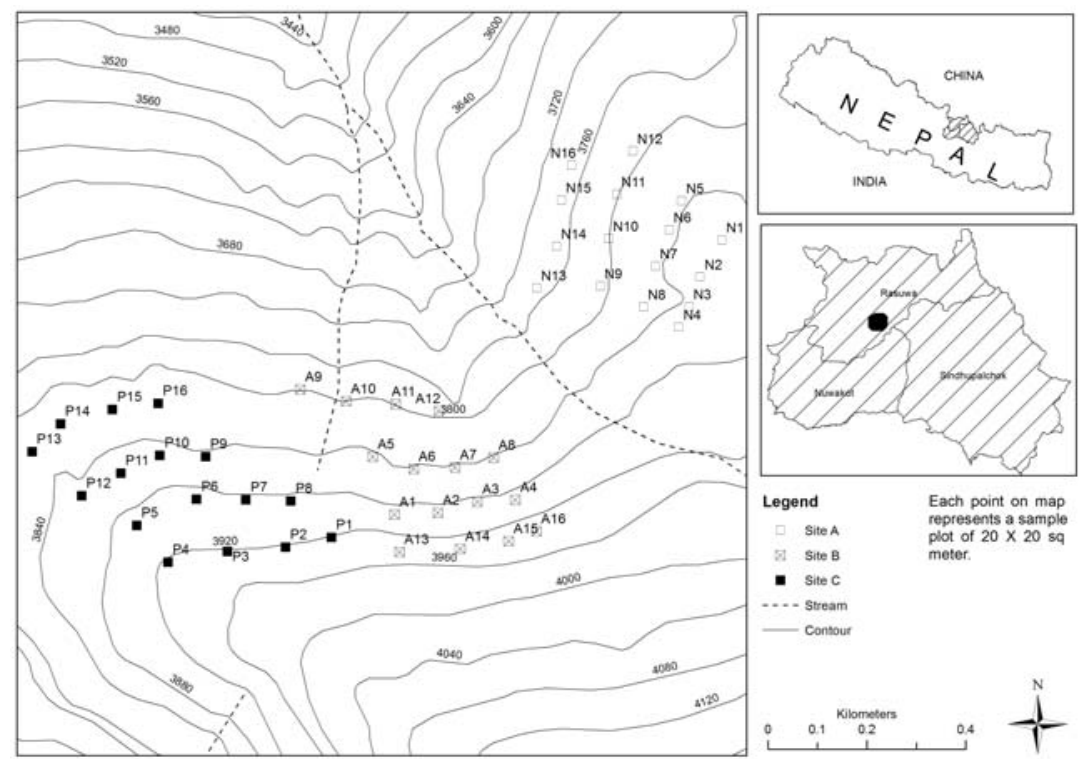

Fig.1. Map showing location of study area and sites: (A) Chaurikharka, (B) between Chaurikharka and Lauribina, and (C) Lauribina, in Langtang National Park, Nepal

Langtang National Park (area: 1,710 sq. km; IUCN category II) is distinguished as having high climatic and altitudinal variations (alt. $792 \mathrm{~m}-7,245 \mathrm{~m}$ asl) (Fig. 1) and is also linked with Qomolongma Nature Reserve in the Tibet Autonomous Region of China. Himalayan endemic (Afganistan to Bhutan), Abies spectabilis (D.Don) Mirb, Himalayan Silver fir (locally recognized as Gobre Salla, Talis patra, Thingre salla), is a large evergreen tree which grows in the lower temperate to lower alpine zone (2,400-4,400 m) in Himalaya (Ghimire et al. 2008). The trees are characterized by low branching with dense foliage. In Nepal it is found in west central and eastern (WCE) region. In its upper distribution limits, it is usually associated with Betula 
Narayan P. Gaire et al./Dynamics of Abies......

utilis and Rhododendron campanulatum which distribute up to the treeline limit (Ghimire et al. 2008). The present study was carried out in three sites of tree-line ecotone: (A) Chaurikharka, (B) between Chaurikharka and Lauribina, and (C) Lauribina covering an area between $85^{\circ} 23.0042 \mathrm{E}$ to $85^{\circ} 23.3192 \mathrm{E}$ and $23^{\circ} 5.6092 \mathrm{~N}$ to $28^{\circ} 5.7732 \mathrm{~N}$ in LNP (Fig. 1).

\section{Ecological and tree-core sampling and data analysis}

Field study was carried out on August to September of 2007. Each individual of the tree species were enumerated into three height classes: trees $(>2 \mathrm{~m})$, saplings (0.5-2 $\mathrm{m})$ and seedlings $(<0.5 \mathrm{~m})$ following classification used in previous studies (Wang et al. 2006, Kullman 2007). Sampling was carried out in four rows at 50m elevation intervals: at Abies tree line, above the tree line, and two below the tree line. Four plots $(20 \mathrm{~m} \times 20 \mathrm{~m})$ were established at each row. A total of 48 plots $(20 \mathrm{~m} \times 20 \mathrm{~m})$ with 16 plots in the each site were established at zone that ranged from 3,730 to 3,950 masl. Each quadrate was surveyed for height and the diameter at breast height (dbh) of all individuals exceeding height of $2 \mathrm{~m}$. Similarly, the number of all sapling and seedlings were recorded from each $5 \mathrm{~m} \times 5 \mathrm{~m}$ and $1 \mathrm{~m} \times 1 \mathrm{~m}$ plots nested in two opposite corners of each $20 \mathrm{~m}$ x $20 \mathrm{~m}$ plots. In addition, the age of representative seedlings and saplings was determined by counting the number of branch whorls and bud scars on the main stem (Wang et al. 2006).

Tree cores of A. spectabilis were collected from the sampling plots by using the Swedish increment borer. Two hundred and twelve cores from 106 trees were collected from the three sites for the analysis and sampling trees was tagged by using permanent plastic plant tags and GPS (e-Trex) record was kept for the references. Collected cores were air dried and glued into grooved sticks with the transverse surface facing up. The surface of cores were cut with the help of sharp razor blade and polished with different grade of sand paper ranging from 100 to 400 grits until optimal surface resolution allowed annual rings to be visible under the microscope. Each ring of the cores was counted and cross dated using skeleton method (Stokes \& Smiley 1968). After dating the tree-ring sequences to exact calendar year of their formations, the width of each ring was measured to the nearest
$0.01 \mathrm{~mm}$ precision with LINTAB ${ }^{\mathrm{TM}}$ measuring system attached to PC.

The quality of dating of each sample was checked using a computer program, COFECH (Holmes 1983). This program checks the error in cross dating due to measurement and other ring width irregularities that might decreases the efficiency of ring-width time series for the tree-ring analysis. The cores that were poorly correlated with the mean chronology or had low correlation, were rechecked and either corrected or eliminated. The corrected ring-width data were standardized using the computer program, ARSTAN (Cook 1985). It removes growth trends related to age and stand dynamics and retained maximum common signal. The ring-width series were standardized using double detrending methods. First, a negative exponential curve or linear trend was fitted to each series, and secondly 30 year's cubic smoothing spline with a 50\% frequency cutoff. Each ring-width-index series was then prewhitened using autoregressive (AR) modeling, to remove any autocorrelation effects (Cook 1987). Finally, three version of chronologies viz. standard, residual and arstan chronologies have been prepared using corrected sample. Various chronologies statistics were also calculated. Correlation analysis was carried out to calculate the tree growth / climate relationship in the software SPSS.

A regression model of $\mathrm{DBH}$ and age was developed to estimate the age of all trees from which increment cores was not collected. The ages from 82 trees were used to form age vs. DBH regression model. In the regression model only those cores which contain both pith and bark were selected. A decade was added to the age of each tree to correct the age for sampling height on the basis of age of seedling and sapling. The regeneration rate or establishment rate was determined using the number of seedling, sapling and tree along with age histogram of tree individuals. Based on the seedling and the sapling densities, the regeneration condition of the forest along the altitude was determined. Dynamics of $A$. spectabilis on its upper limit was analyzed by observing the elevation wise distribution of tree, sapling, and seedling densities as well as using the total tree age histogram and elevation wise age distribution. 


\section{Results and Discussion Local Climate Trend}

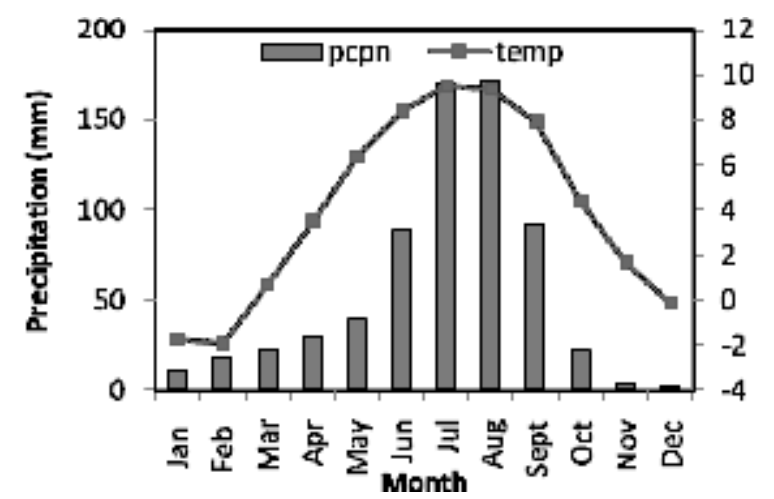

Fig. 2. Monthly mean temperature and precipitation (mm) recorded in Kyanjing Meteorological station (Source: DHM 2007)

The meteorological station nearest to the study area LNP was Kyanjing (3,920m asl) in Rasuwa district. Available data (1988 to 2007) showed that average monthly total rainfall was maximum in August (172.76 $\mathrm{mm})$ followed by July (171.14 $\mathrm{mm}$ ) and the minimum was in December (2.57 mm) (Fig.2). There was $0.163^{\circ} \mathrm{C}$ per year increment in the winter minimum temperature and the increment was statistically significant $(r=0.51$, $\mathrm{p}<0.02$ ). There was an increment on annual total rainfall by a rate of $10.73 \mathrm{~mm}$ per year, this increment was statistically significant $(r=0.49, \mathrm{p}<0.03)$.

\section{Site chronology of Abies spectabilis and Tree growth-climate relationship analysis}

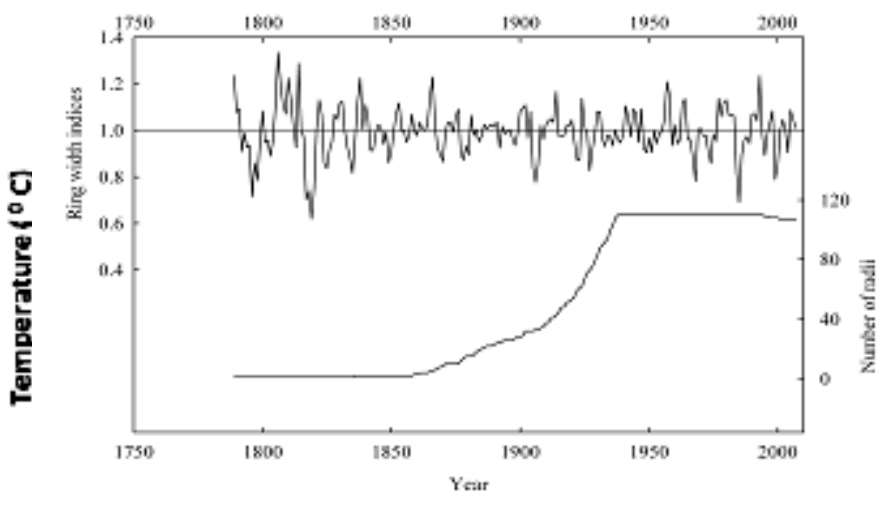

Fig. 3. Tree ring chronology of A. spectabilis at LNP

Out of 212 cores from 106 trees, 110 cores from 67 trees were successfully cross dated. Finally, 218 years long chronology was prepared which extends from AD 1789-2007 (Fig. 3). Various chronologies statistics were calculated for the time span of AD 1789-2007 and also for the common period of all series (AD 19312007) of Abies chronology to describe site chronologies. A species with a low autocorrelation, a high mean sensitivity and a high standard deviation has good potential for dendroclimatological studies (Fritts 1976).

Table l. Selected statistics of tree-ring chronology of Abies spectabilis at Lauribina, LNP

\begin{tabular}{lcc}
\hline & Standard Chronolog & Residual Chronology \\
\cline { 2 - 3 } Chronology Time Span: & A.D. 1789-2007 & A.D. 1789-2007 \\
Number of Trees (radii): & $67(110)$ & $67(110)$ \\
Mean Sensitivity. & 0.084 & 0.102 \\
Standard Deviation: & 0.105 & 0.093 \\
AR modeling & 0.465 & 0.034 \\
Autocorre lation order 1: & & AR 2 \\
Cornmon Interval Time Span: & A.D. 1931-2007 & A.D. $1931-2007$ \\
Number of Trees (radii): & $48(76)$ & $48(76)$ \\
Mean correlation among all radii: & 0.310 & 0.341 \\
Mean correlation between trees & 0.308 & 0.339 \\
Mean correlation within trees: & 0.578 & 0.592 \\
Signal-to-noise ratio: & 38263 & 43.962 \\
Expresed population signal: & 0.975 & 0.978 \\
Variance Explained: & $432 \%$ & $44.6 \%$ \\
\hline
\end{tabular}


Narayan P. Gaire et al./Dynamics of Abies......

The statistical characteristics of the tree-ring series are shown in Table 1. Mean sensitivity is a measure of the relative difference in width between consecutive rings (Fritts 1976). Possible values range from 0 (indicating no change in ring width from one year to the next) to 2 (indicating a missing ring), with high mean sensitivity measurements interpreted as an indication that the ring-width series may have dendroclimatological utility (Fritts 1976). In the present study the value of mean sensitivity was 0.084 and 0.102 for standard and residual chronology, respectively (Table 1). In the present chronology the value of first order autocorrelation in standard chronology is 0.465 . The values of First-order autocorrelation have been decreased (0.034) after applying AR modeling. Mean series correlation within trees, between trees and among all the radii is calculated. The values of mean correlation within tree in both standard and residual chronology are high (0.578 and 0.592 respectively) as compare to mean correlation between tree and among all radii (Table 1). Expressed population signal (EPS) is an indication of how well the site chronology estimates the population chronology (Wigley et al. 1984). An EPS of 0.85 (i.e., 85\%) is suggested as threshold limit (Wigley et al. 1984) and it exceeds here in both standard and residual chronology (0.975 and 0.978 respectively) (Table 1). Signal to Noise ratio is a measure of the common variance in a chronology scaled by a measure of the total variance of the chronology. Signal to Noise ratio in standard chronology is 38.263. The values of this have been increased (43.962) after applying AR modeling (Table 1).

Due to the lack of sufficient data at nearby station from study site, climate data (mean temperature and total monthly precipitation) of Kathmandu airport (alt. $1,324 \mathrm{~m}$; location $27^{\circ} .702 \mathrm{~N}: 85^{\circ} .202 \mathrm{E}$ ) was used to derive tree-growth climate relationship.
Those data also have shown warming trends in recent years. Program MET from the Dendro PROGLIB library was used to compute the missing values in the climatic series.

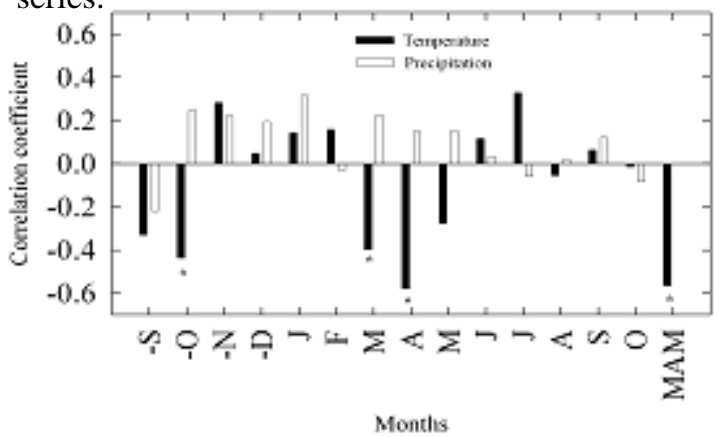

Fig. 4. Tree growth and climate relationship, the asterisk over the bar indicates the relation is statistically significant

The tree growth climate relationship based on the correlation analysis shows significant negative correlation with temperature of current year MarchApril and October of previous year (Fig. 4). Negative correlation with May temperature of the current year is also noticed but significant level is low in comparison to March-April temperature. The relationship was again carried out with the seasonal pre-monsoon temperature (i.e., March-May temperature) and found significantly negative correlation at $\mathrm{p}<0.05$. Similar response are also recorded in tree-ring work carried out in other region of Nepal viz. western Nepal (Sano et al. 2005) and central Nepal (Chhetri \& Thapa 2010). No significant correlation is observed with precipitation. The negative relationship with the premonsoon temperature may cause the increase in evapo-transpiration which leads to soil-moisture deficit and limits the tree-growth.

\section{Regeneration and treeline dynamics of Abies spectabilis}

Table 2. Structural parameters of Abies spectabilis at tree line ecotone, LNP, Nepal

\begin{tabular}{|c|c|c|c|c|c|c|c|c|c|c|}
\hline \multirow[b]{2}{*}{ sire } & \multirow[b]{2}{*}{$\begin{array}{l}\text { Basal } \\
\text { Area } \\
\text { (me/ha) }\end{array}$} & \multirow[b]{2}{*}{$\begin{array}{l}\text { Densily } \\
\text { (Nol } \\
\text { ha) }\end{array}$} & \multicolumn{2}{|c|}{ Tree } & \multirow[b]{2}{*}{$\begin{array}{l}\text { Max } \\
\text { DBH } \\
\text { (cm) }\end{array}$} & \multirow[b]{2}{*}{$\begin{array}{l}\text { Canopy } \\
\text { cover } \\
\text { (\%) }\end{array}$} & \multicolumn{2}{|c|}{ Sapling } & \multicolumn{2}{|c|}{ Seedling } \\
\hline & & & $\begin{array}{l}\text { Frequency } \\
\text { (\%) }\end{array}$ & $\begin{array}{l}\text { Mean } \\
\text { DBH } \\
\text { (cm) }\end{array}$ & & & $\begin{array}{l}\text { Density } \\
\text { (No/ha) }\end{array}$ & $\begin{array}{c}\text { Frequency } \\
(\%)\end{array}$ & $\begin{array}{l}\text { Densiny } \\
\text { (No/ha) }\end{array}$ & $\begin{array}{c}\text { Frequency } \\
\text { (\%) }\end{array}$ \\
\hline A & 9.83 & 172 & 63 & 18.4 & 116 & 38.35 & 272 & 37.5 & 315 & 37.5 \\
\hline B & 9.4 & 277 & 88 & 17.2 & 72 & 27.9 & 265 & 62.5 & 479 & 37.5 \\
\hline C & 19.2 & 257 & 92 & 26.3 & 94 & 42.5 & 228 & 62.5 & 256 & 75 \\
\hline Average & 12.8 & 236 & 80.6 & 20.6 & 116 & 36.25 & 255 & 54.17 & 350 & 50 \\
\hline
\end{tabular}


Summary of different structural parameters (density of tree, sapling, and seedling and canopy coverage) of $A$. spectabilis in three sites are given in Table 2 . The average basal area was found to be $9.83 \mathrm{~m}^{2}$ per ha, $9.4 \mathrm{~m}^{2}$ per ha and19.2 $\mathrm{m}^{2}$ per ha in site A, B and C respectively. Tree density for the three sites was found to be 172, 277 and 257 no/ha, respectively. The mean DBH was found $20.6 \mathrm{~cm}$. Some dead or damaged trees were also recorded which accounted 2 no/ ha with basal area $0.22 \mathrm{~m}^{2}$ per ha. The average tree density was 236 no per hectare and which was 172, 277 and 257 no/ha, respectively for site A, B and C. Similarly sapling density was found 272, 265 and 228 no/ha whereas, seedling densities was 315, 479, 256 no /ha, respectively for site $\mathrm{A}, \mathrm{B}$ and $\mathrm{C}$. The canopy coverage of tree species is $38.35,27.9,42.5 \%$, respectively, for site A, B and C. There was a general trend that tree canopy cover decreased with an increase in elevation. The elevation wise distribution of tree, sapling and seedling densities was presented in Figs.5a-c. In general there was negative relationship of tree, seedling, and seedling densities with elevation. All tree, sapling and seedling densities were decreased with increasing elevation (Fig. 5a-c), the decrease was statistically significant. However, there was some site specific variation on seedling and sapling density.

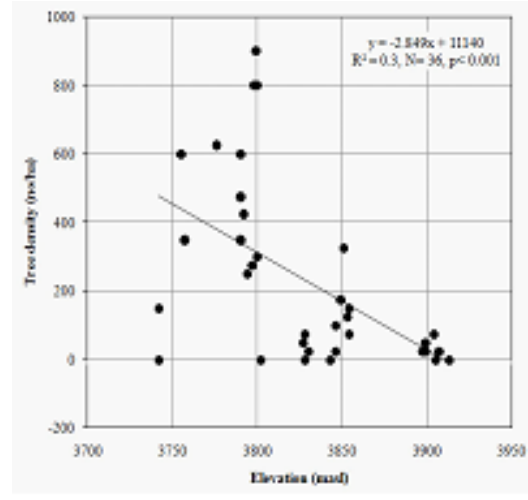

Fig $5 \mathrm{a}$

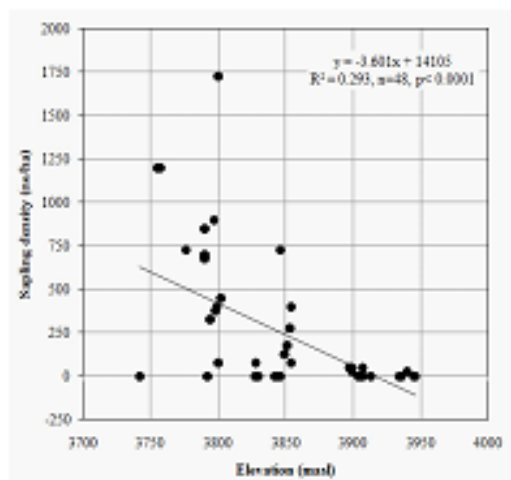

Fig $5 b$

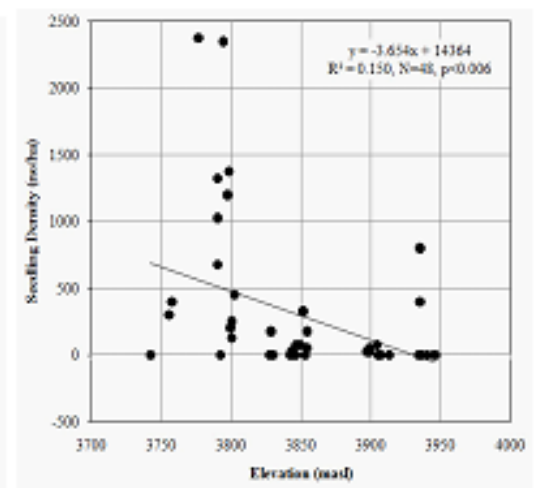

Fig $5 \mathrm{c}$

Fig. 5a-c. Elevation wise distribution of tree, sapling and seedling densities

The observed Abies tree density is higher than that from tree line and lower than timberline of Sagarmatha region (Bhuju et al. 2010) which might be due to lower elevation of present tree line and/or higher regeneration of tree. Though spatial heterogeneity in tree densities in studied sites, there was a decreasing trend of tree density with elevation, which is consistent with the finding of studies from treeline ecotones of the Nepal Himalaya: in trans-Himalaya (Shrestha et al. 2007), central (Suwal 2009) and Eastern Himalaya (Bhuju et al. 2010). The basal area ratio of the present studied tree line is less than the basal area ratio reported from trans-Himalayan treeline (Shrestha et al. 2007) and higher than treeline ecotone of Sagarmatha region (Bhuju et al. 2010). Average seedling density (350 no/ ha) of A. spectabilis was higher than that of sapling (255 no/ha), which is a normal demographic development (Vetaas 2000), and is similar to the result of a study from Manang (Ghimire \& Lekhak 2007). The seedling and sapling ratio of tree species shows no general trend with elevation in all sites but in site A there was trend of increasing proportion of seedling with increasing elevation.

Regeneration of canopy dominants trees can be assessed by the distribution of size-classes measured as diameter at breast height (West et al., 1981). The diameter class distribution of the Abies spectabilis in this study showed an inverse J-shape (Fig. 6) which is indication regeneration (Vetaas 2000). The size class $5-10 \mathrm{~cm}$ consists of maximum number of individuals. However, class $<5 \mathrm{~cm}$ consists less individuals which is due to height criteria taken to separate individual as tree, sapling and seedling. In a similar study of $A$. spectabilis from Sagarmatha region a bell-shaped and an inverse J-shaped diameter distribution was observed at tree line and timberline (Bhuju et al. 2010). In individual class level, there were some clefts indicating tree cutting or other damage at times or episodic recruitment of trees. 


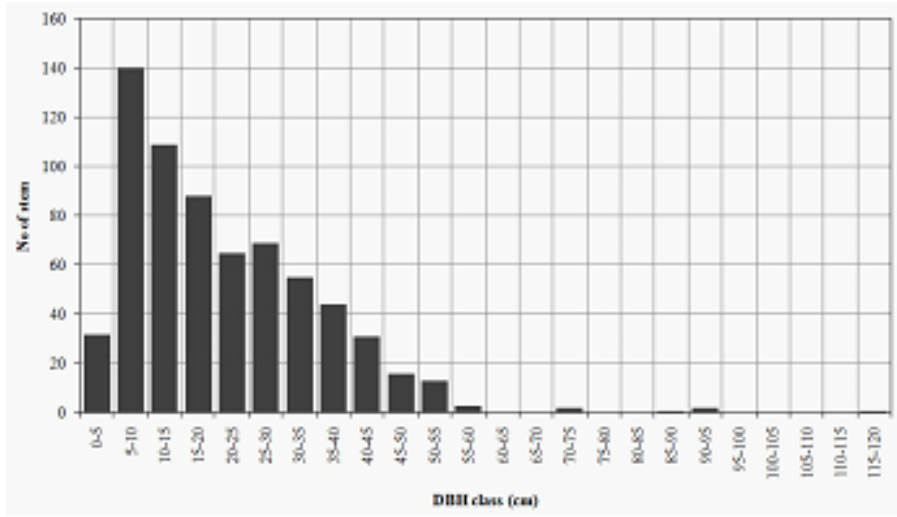

Fig.6. Diameter class distrbutions of Abies spectabilis in three sites

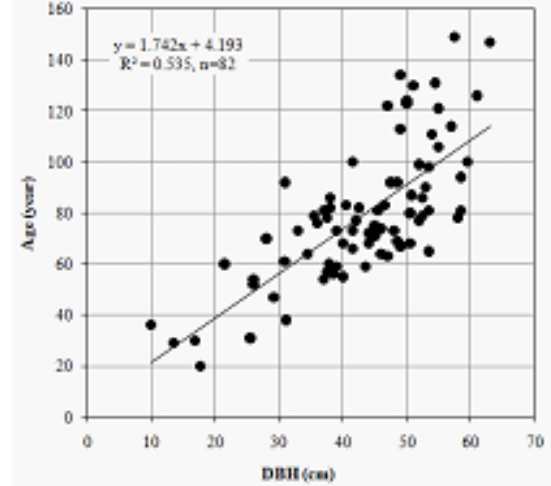

Fig. 7. DBH-Age re lationship of $A$. spectabilis in the study area
A regression analysis model between $\mathrm{DBH}$ and age of Abies was established. The correlation between age and DBH of trees was positive and statistically significant ( $n=82, r=0.732, p<0.0001$ ) (Fig. 7), and this relationship was used to estimate the age of all Abies trees which were not analyzed dendrochronologically. Similar to the DBH frequency distribution, the age-frequency of $A$. spectabilis also displayed an inverse J-shaped distribution (10-year intervals) (Fig.8). Age histograms for A. spectabilis showed that trees could be dated back to the late eighteenth century and was dominated by young individuals. Up to late nineteenth century (before1900s) establishment was seemed very poor with old individuals ( $>100$ years) accounting for only $2 \%$ of the total population. The majority of trees (>80\%) were established after 1950s. There was gap in age distribution in many age classes that might be due to disturbance in past or episodic recruitment of individuals. The maximum age of sampled saplings $(<2 \mathrm{~m})$ was 17 years and maximum age of sampled seedlings $(<0.5 \mathrm{~m})$ was 12 years. The age of sapling and seedling was not included in this age distribution histogram. Average age of $A$. spectabilis was decreased with increasing altitude. The age distribution of this study was similar with stand age distribution observed in tree line ecotone of Eastern Nepal (Bhuju et al. 2010). If the age of sapling and seedling included in the age distribution then the percentage of young individual further increase because sum of the number of sapling and seedling stems was much higher than recorded total number of trees. The result based on stand character, is similar to studied carried out in other sites (Kullman 2007, Bhuju et al. 2010).

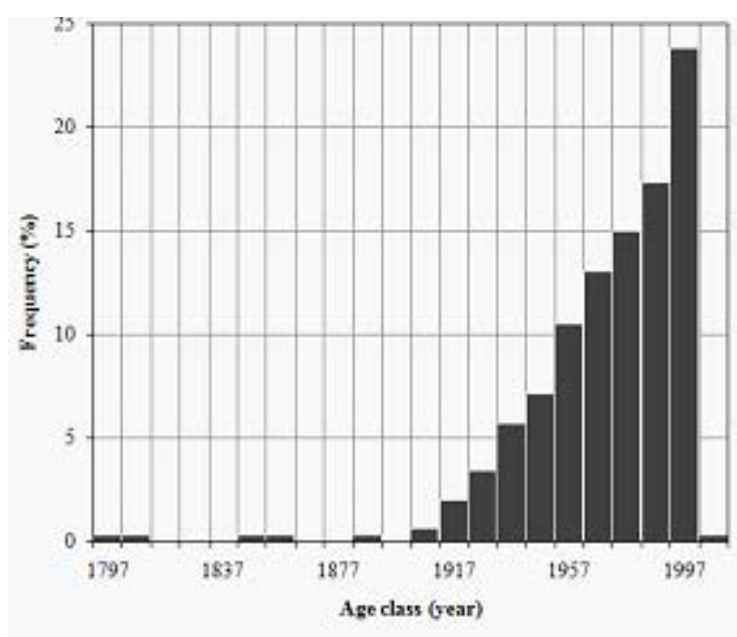

Fig. 8. Age frequency histogram of Abies spectabilis (10 year class) with calendar time.

Tree establishment at the tree line ecotone may be controlled by local micro-environmental factors and episodic climatic events, leading to years of either low or high mortality (Szeicz \& Macdonald 1995). Sapling and seedling distribution of Abies was spatially heterogeneous. Spatial heterogeneity in sapling and seedling distribution may be determined by light availability caused by canopy cover, inability of seedling to grow in its upper distribution limit, soil conditions, etc. Irrespective of sites, in present study there was significant positive linear relationship between seedling density with the tree canopy cover $(\mathrm{r}=0.44, \mathrm{p}<0.002))$ and between sapling and tree canopy $(\mathrm{r}=0.47, \mathrm{p}<0.001)$. A dense krummholz-belt can provide shelter against the harsh tree line environmental 
conditions like strong wind and abrasion by ice, low temperature (Hadley \& Smith 1987), however, in this area such dense krummholz-belt is not present. The strong relation of saplings with canopy might be due to its shelter against snow fall damage because for seedlings canopy coverage of saplings also provides shelter against damage by snow fall at winter. The heterogeneous distribution of seedling and sapling may be linked with canopy cover as also observed by Shrestha et al. (2007).

The upward shift of tree line is almost globally accepted phenomenon, although the magnitude and rate of advancement, population growth and stand densification vary on local environmental conditions (Meshinev et al. 2000, Kullman 2001, Suwal 2009). Some tree line individuals can persist for decades to centuries during harsh climatic periods and respond with an accelerated vertical growth in response to improved climatic conditions and if the climatic threshold is exceed due to an extreme climatic event like severe frost or intense warming tree line shifts could result (Camarero \& Gutiérrez, 2004). In this study, importantly, some seedlings and saplings were persisted at much higher elevation position than the cone bearing tree individuals, probably, indicating upward migration with temperature increase in recent past. Hence, though there is heterogeneous distribution of sapling and seedling, high recruitment of $A$. spectabilis in recent decades as well as decrease of average age with increasing altitude, the upward advancement of upper limit of this species during recent decades can be anticipated. This might be facilitated by increased winter minimum temperature leading to early melting of snow in the study area.

This present study documented the recruitment dynamics and tree ring data of Abies spectabilis at the tree line of the high mountains of Langtang National Park, the Nepal Himalaya. In spite of short period's data from local stations, the available climatic data document climatic warming in recent years. The stand character and age distribution showed there was high level of recruitment of $A$. spectabilis in the recent decades with decrease in average age with increasing altitude, so the upward advancement of upper limit of this species can be expected. To quantify the rate of dynamics or shifting of treeline with climate change, careful, a long term and detail study of different climatic, ecological and dendrochronological aspect is necessary for which present study will be reference information.

\section{Acknowledgements}

We are thankful to Department of National Parks and Wildlife Conservation for the permission and providing necessary facilities during collection of samples. Department of Hydrology and Meteorology provided with climatic data. We thank Mr Suman Aryal and $\mathrm{Mr}$ Ranjit Pande for their help during field work and to $\mathrm{Mr}$. Madan Krishna Suwal for location map preparation. We are grateful to Dr. Amalava Bhattacharyya of Birbal Sahni Institute of Paleobotany. This work was partly supported by mentorship program of Resources Himalaya Foundation, Nepal.

\section{References}

Abrams, M.D., C.M. Ruffner and T.E. DeMeo. 1998. Dendroecology and species co-existence in an old-growth Quercus-Acer-Tilia talus slope forest in the central Appalachians, USA. Forest Ecology and Management 10 (6): 9 - 18.

Becker, A., C. Korner, J.J. Brun, A. Gusian and U. Tappeiner. 2007. Ecological and Land Use Studies Along Elevational Gradients. Mountain Research and Development 27(1):59-65.

Bhattacharyya, A., V.C. Lamarche, JR and M. K. Hughes. 1992. Tree ring chronologies from Nepal. Tree Ring Bulletin 52:59-66.

Bhuju, D.R., M. Carrer, N.P. Gaire, L. Soraruf, R. Riondato, F. Salerno and S.R. Maharjan. 2010. Dendroecological study of high altitude forest at Sagarmatha National Park, Nepal. In: Contemporary research in Sagarmatha (Mt. Everest) region, Nepal (eds. Jha, P.K. and I.P Khanal). Nepal Academy of science and Technology, Khumaltar, Lalitpur. 2010, pp.119-130.

Bradley, R.S. and P.D. Jones. 1993. 'Little Ice Age’ summer temperature variations: their nature and relevance to recent global warming trends. The Holocene 3: 367376.

Bräuning, A. 2004. Tree-ring studies in the Dolpo-Himalya (western Nepal). In: E. Jansma, A. Bräuning, H. Gärtner, and G. Schleser, eds., Tree Rings in Archaeology, Climatology and Ecology 2(44):8-12. Schriften des Forschungszentrum Jülich, Reihe Umwelt.

Camarero, J.J. and E. Gutiérrez. 2004. Pace and pattern of recent tree line dynamics: response of ecotones to climatic variability in the Spanish Pyrenees. Climatic Change 63: 181-200. 
Chhetri, P.K. and S. Thapa. 2010. Tree Ring and Climate change in Langtang National Park, Central Nepal. Our Nature 8: 139 -143.

Cook, E.R. 1985. A time series analysis approach to treering standardization. $\mathrm{PhD}$ dissertation, University of Arizona, Tucson, AZ.

Cook, E.R. 1987. The decomposition of tree-ring series for environmental studies. Tree-Ring Bulletin 47: 37-59.

Cook, E.R., P.J. Krusic and P.D. Jones. 2003. Dendroclimatic Signals in Long Tree- Ring Chronologies from the Himalayas of Nepal. International Journal of Climatology 23: 707-732. (www.interscience.wiley.com). DOI: 10.1002/joc.911

Fritts, H.C. 1976. Tree Rings and Climate. Academic Press. London.

Ghimire, B. and H.D. Lekhak. 2007.Regeneration of Abies spectabilis (D.Don) Mirb.in Subalpine Forest of Upper Manang, North -central Nepal. In : Local effects of Global Changes in the Himalayas: Manang,Nepal,2007.( Eds.:R.p.Chaudhary, T.S.Aase,O.R.Veetaas, B.P. Subedi). Tribhuvan University, Nepal and University of Bergen, Norway. pp139-149

Ghimire, S.K., I.B. Sapkota, B.R. Oli and R. Rai Prajuli. 2008. Non timber forest products of Nepal Himalaya. WWF Nepal, Kathmandu Nepal.

Hadley, J.L. and W.K. Smith. 1987. Influence of krummholz matmicroclimatic on needle physiology and survival. Oecologia 73: 82-90.

Harcombe, P.A. 1987. Tree life table. Bioscience 37: 557_ 568.

Körner, C. 1998. A Re-assessment of High Elevation Tree line Positions and their Explanation. Oecologia 115:445459.

Kullman, L. 1998. Tree-limits and montane forests in the Swedish Scandes: sensitive biomonitors of climate change and variability. Ambio. 27: 312-321.

Kullman, L. 2001. 20th century climate warming trend and tree-limit rise in the southern Scandes of Sweden. Ambio. 30: 7 2-80.

Kullman, L. 2007. Tree line population monitoring of Pinus sylvestrisin the Swedish Scandes, 1973-2005: implications for tree line theory and climate change ecology. Journal of Ecology 95: 41-52.

Meshinev, T., I. Apostolova and E. Koleva. 2000. Influence of warming on timberline rising. A case study in Pinus peuce Griseb. in Bulgaria. Phytocoenologia 30: 431-438.
Sano, M., F. Furuta, O. Kobayashi and T. Sweda. 2005. Temperature variations since the mid-18th century for western Nepal, as reconstructed from tree-ring width and density of Abies spectabilis. Dendrochronologia 23: 83-92.

Schild, R., 2007. The Mountain Perspective as an Emerging Element in the International Devlopment Agenda. Sustainable Mountain Devclopment No. 53. ICIMOD, Lalitpur, Kathmandu Nepal.

Shrestha, B.B., B. Ghimire, H.D. Lekhak and P.K. Jha. 2007. Regeneration of Tree line Birch (Betula Utilis D.Don) Forest in trans-Himalayan Dry Valley in Central Nepal. Mountain Research and Development 27(3):250-258. doi:10.1659/mred.0784

Shrestha, A.B., C.P. Wake, P.A. Mayewski and J.E .Dibb. 1999. Maximum Temperature Trend in the Himalaya and its vicinity: An analysis based on temperature records from Nepal for period 1971-94. Journal of Climate 12: 2775-2787.

Stokes, M.A. and T.L. Smiley. 1968. An Introduction to Tree Ring Dating. University of Chicago Press, Chicago, USA, 73pp.

Suwal, M. K. 2010. Tree species line advance of Abies spectabilis in Manaslu Conservation Area, Nepal Himalaya. M.Sc. Thesis. Central Department of Botany, Tribhuvan University, Kathmandu Nepal.

Suzuki, E. 1990. Dendrochronology in coniferous forests around Lake Rara, west Nepal. Botanical Magazine Tokyo, 103:297-312.

Szeicz, J.M. and G.M. MacDonald. 1995. Recent white spruce dynamics at the subarctic alpline tree line of north-western Canada. Journal of Ecology 83: 873885.

Vetaas, O.R. 2000. The effect of environmental factors on regeneration of Quercus semecarpifolia Sm. in central Himalaya, Nepal. Plant ecology 146:137-44.

Wang, T., Q-B. Zhang and K. Ma. 2006. Tree line dynamics in relation to climatic variability in the central Tianshan Mountains, northwestern China. Global Ecology and Biogeography 15: 406-415.

Wigley, T. M.L., K. R. Briffa and P.D Jones 1984. On the average value of correlated time series, with applications in dendroclimatology and hydrometeorology. Journal of Climate and Applied Meteorology 23:201-13.

West, D.C., H.H. Shugart and J.W. Ranney. 1981.Population structure over a large area. Forest Science 27:701-710. 
Nepal Journal of Science and Technology 12 (2011) 220-229 